\title{
Mesenchymal stem cells as a possible therapy in experimentally induced retinal damage in Albino rat: Histological study
}

\section{Original Article}

\author{
Fika Hassan Kamel El Ebiary, Mohamed Abd Elrahman Ahmed Mekawy, Abeer A. \\ Abd El Samad and Eman A. Negm
}

Department of Histology, Faculty of Medicine, Ain-Shams University, Cairo, Egypt

\begin{abstract}
Introduction: Retinal degeneration had been increased as a common cause of blindness nowadays. Stem cells could be a promising therapy for treating retinal degeneration.

Aim of the work: To investigate the possible role of BMSCs on the damaged retina resulting from continuous fluorescent light exposure.

Materials and Methods: Twenty- five albino rats (80-100) gm were used in this study. Of which, 5 rats were used for preparation of the BMSCs. The other twenty adult rats were divided into three groups. Rats of the control group were kept in $12 \mathrm{hrs} \mathrm{light/12} \mathrm{hrs} \mathrm{dark.} \mathrm{Rats} \mathrm{of} \mathrm{group} \mathrm{II} \mathrm{(fluorescent} \mathrm{light} \mathrm{exposure} \mathrm{group)} \mathrm{were} \mathrm{exposed} \mathrm{to} \mathrm{two} \mathrm{20W} \mathrm{white} \mathrm{fluorescent} \mathrm{lamps}$ $60 \mathrm{~cm}$ length continuously for 2 weeks at an illumination of 500 Lux. Group II rats were examined 8 weeks after fluorescent light exposure. Group III animals were injected once by PKH 26-labeled BMSCs into the vitreous cavity of the eye at the end of the second week of fluorescent light exposure and kept for 8 weeks. Retinal specimens were prepared for light (LM) and electron microscopic (EM) examination. Morphometric and statistical study was performed.

Results: Sections of group II showed thinning and disorganization of outer segments. There were spaces and disorganization of the cells of the outer and inner nuclear layers. Most ganglion cells had vacuolated cytoplasm and some appeared with dense nuclei. Most of retinal cells had distorted organelles. Immunohistochemical reaction revealed significant increase in GFAP immune reaction. Statistical analysis revealed a significant decrease in the thickness of most retinal layers. Meanwhile, group III retinas showed restoration of most of the histological structure.

Conclusion: BMSCs could ameliorate retinal degeneration resulted from continuous fluorescent light exposure.
\end{abstract}

Received: 27 May 2018, Accepted: 5 June 2018

Key Words: BMSCs, fluorescent light, rat, retinal degeneration.

Corresponding Author: Eiman A. Negm, Department of Histology, Faculty of Medicine, Ain-Shams University, Cairo, Egypt, Tel.: 01068659922, E-mail: emystar666@gmail.com.

ISSN: $1110-0559$, Vol. 41 , No. 3

\section{INTRODUCTION}

World-wide, retinal diseases such as glaucoma, agerelated macular degeneration, proliferative diabetic retinopathy and other degenerative retinal diseases that can end in blindness are estimated to affect more than $12 \%$ of individuals over the age of $40^{[1]}$.

Exposure to high levels of visible light was found to cause hyper permeability of retinal pigmented epithelium leading to degeneration of photoreceptors ${ }^{[2]}$. Nowadays, fluorescent light is the most common artificial source of lighting. Retinal light injury was found to be caused by environmental exposure to fluorescent light ${ }^{[3]}$.

Over the past few years, identification and characterization of stem cells led to potential use of them as a promising cell replacement therapy. The use of stem cells as a therapeutic option for treating retinal dystrophies might help to restore vision by repopulating the damaged retina and rescuing retinal neurons from further degeneration ${ }^{[4]}$.

Many attempts to regenerate retina with neural stem cells have been made. Experimental transplantation of brain derived stem cells, bone marrow - derived neural stem cells and retinal specific progenitors in experimental models of retinal degeneration have resulted in mixed success $^{[5]}$.

On the other hand, the human embryonic stem cells have the potential to differentiate into retinal cells and their retinal microenvironment supports their differentiation towards a photoreceptor fate ${ }^{[6]}$. These findings widen the prospects of the potential use of these cells for retinal regeneration. Human embryonic stem cells (hESCs)-derived retinal pigment epithelial (RPE) cells were successfully transplanted into patients with macular degeneration with limited adverse events due to immunosuppressive regimen on long term transplantation ${ }^{[7,8]}$. 
Bone marrow mesenchymal stem cells (BMSCs) have become the cells of choice in cell-based therapy because of their autologous characteristics, multipotency, relative ease of isolation and high culture expansion ${ }^{[9]}$. BMSCs proven to be safe and well-tolerated when administered intravitreally in rabbits ${ }^{[10]}$.

\section{AIM OF THE WORK}

To study the possible therapeutic role of bone marrow mesenchymal stem cells on the damaged retina exposed to continuous fluorescent light in adult male albino rats.

\section{MATERIALS AND METHODS}

Twenty-five albino rats $180-200$ gm were used in this work Five rats were used for preparation of the BMSCs. The animals were maintained in clean wire mesh cages under standard laboratory conditions of humidity and temperature with free access to food and water. The whole experiment was carried out in the Animal Research Center in accordance with the animal care and use guidelines of the scientific research Ethical Committee of Faculty of Medicine, Ain Shams University.

The twenty adult male rats were divided into three groups as follow:

Group I: (control group): included 10 rats: Animals of this group were subdivided into two equal subgroups; 5 animals each: Subgroup Ia: Animals of this subgroup were housed in normal cyclic light environmental conditions (12 hours of light and 12 hours of darkness) for 2 weeks then kept for 8 weeks.

Subgroup Ib: Animals of this subgroup were subjected to normal cyclic light conditions for 2 weeks. After that, the animals were slowly injected in the vitreous cavity (upper nasal part, $1 \mathrm{~mm}$ from the limbus) with $20 \mu 1$ of phosphate buffered saline (PBS) and kept for 8 weeks after injection.

Group II: (fluorescent light exposure group) included 5 rats: Animals of this group were put in top opened (fenestrated) cages illuminated continuously by two $20 \mathrm{~W}$ white fluorescent lamps $60 \mathrm{~cm}$ length for two weeks. The lamps were hung up at a distance of $30 \mathrm{~cm}$ from the animal cages at an illumination of 500 Lux $^{[11]}$. Animals of this group were kept for 8 weeks after fluorescent light exposure.

Group III: (BMSCs injected group) included 5 rats: Animals of this group were subjected to fluorescent light as in group II for 2 weeks. At the end of the second week, a cell suspension $(20 \mu 1)$ containing approximately $4 \times 105$ of PKH 26-labeled BMSCs was slowly injected into the vitreous cavity of each animal ${ }^{[12]}$ and they were kept for 8 weeks after injection.

At the end of the experiment in all groups, the animals were generally anesthetized with diethyl ether. The right eyeballs were injected with $10 \%$ neutral buffered formalin for light microscopic study and the left ones were injected with 5\% phosphate buffered glutaraldehyde for electron microscopic study. The eyeballs were then enucleated. The cornea and lens were removed and the posterior part including the retina was preserved in the same solutions.

For light microscopic study, paraffin blocks were prepared from the retina and $5 \mu \mathrm{m}$ thick serial sections were obtained and stained with:

1- Hematoxylin and Eosin stain $(\mathrm{H} \& \mathrm{E})^{[13]}$.

2- Immunohistochemical staining:

Glial fibrillary acidic protein (GFAP) antibody purchased from Bio genex, USA was used to detect astrocytes and other glial cells in a ready to use technique. Sections were deparaffinized in xylene for one hour. Two drops of primary antibody were applied and incubated for one hour at room temperature then washed twice with PBS. Two drops of biotinylated secondary-antibody were applied and then incubated for 30 minutes at room temperature then washed twice with PBS. Two drops of DAB solution were applied to all sections and incubated for ten minutes. Then sections were washed in distilled water and counterstained with Mayer's haematoxylin for two minutes. Negative control sections were processed by replacing the primary antibody by phosphate buffer saline ${ }^{[13]}$.

For transmission electron microscope, small pieces of the retina $\left(1-2 \mathrm{~mm}^{3}\right)$ were fixed at $4^{\circ} \mathrm{C}$ in phosphate buffered glutaraldehyde. The specimens were processed for semithin sections ( $1 \mu \mathrm{m}$ thick). These sections were stained with $1 \%$ toulidine blue and examined by light microscope. Ultrathin sections were stained with uranyl acetate and lead citrate and examined with transmission electron microscope (JEOL-JEM- 1010) at the Regional Center for Mycologyand Biotechnology (RCMB), Al Azhar University and electron micrographs were taken.

BMSCs were isolated from the five young rat femurs and tibias for culture and to be labeled by PKH26.

BM-MSCs were characterized through flowcytometry (14) to confirm that these cells maintain their phenotypic characteristics after growth in culture.

\section{Morphomrtric and statistical study}

The mid-center region of the retina in five different stained sections from five different rats were examined in each group, (five high power fields /section) to measure:

a) The mean thickness of outer nuclear layer.

b) The mean thickness of inner nuclear layer.

c) The mean area percentage of GFAB positive immune reaction.

The measurements were done by using an image analyzer Leica Q win V.3 program installed on a computer in the Histology Department, Faculty of Medicine, Ain Shams University. The computer was connected to a Leica 
DM2500 microscope (Wetzlar, Germany).

The measurements were expressed as mean \pm SD and statistically analyzed for significant differences between groups using IBM SPSS statistics software (version 20 IBM Corporation, New York, USA). The comparison in the measured data among different groups was statistically analyzed using one-way analysis of variance (ANOVA).

The probability of chance ( $p$ value) is used to determine the significance of data:

- $P$ value $\geq 0.05$ is statistically insignificant.

- $P$ value $<0.05$ is statistically significant.

\section{RESULTS}

\section{I) Morphology of the primary culture of rat BMSCs as evident by the phase contrast microscope:}

Examination of the rat bone marrow primary culture on days 1, 3, 4 and 6 was done. On day seven, the cells in culture were stained with Giemsa stain. The cells were mostly confluent. The cells had multiple inter-digitating processes. The cytoplasm of the cells appeared bluish, granular with vesicular nuclei (Fig. 1).

On day five after subculture, the attached cells formed colonies. Most of the cells were spindle shaped and star shaped with granular cytoplasm and vesicular nuclei (Fig. 2).

\section{II) Characterization of BMSCs by flowcytometry (Histogram 1)}

Flow cytometry analysis revealed that the cultured cells after subculutured them expressed CD 29 (Histogram 1a), CD 90 (Histogram 1b). However, they did not express CD 34 (Histogram 1c). The cells maintained their phenotype characters throughout the passages.

\section{III) Light microscopic examination of the rat retina}

Examination of H\&E stained retinal sections of the control group showed from the choriod to the vitreous body, the retinal pigment epithelium (RPE) which appeared as a row of rounded cells with flattened nuclei. The photoreceptor layer contained the rod and cone cells. The outer limiting membrane (OLM) was seen between the inner segment of photoreceptor cells and the outer nuclear layer. The outer nuclear layer (ONL) formed of densely packed nuclei of rod and cone cells. The outer plexiform layer (OPL) was seen between ONL and inner nuclear layer (INL). It contained blood vessels. The nuclei of INL appeared larger and paler in comparison to the outer nuclear layer. The inner plexiform layer (IPL) was located between the INL and the ganglion cell layer (GCL). It appeared thicker than the outer plexiform layer. The ganglion cell layer was formed of rounded and variable sized cells. These cells were paler, larger than those of the other nuclear layers. The nerve fiber layer (NFL) was composed of axons of the ganglion cells. The inner limiting membrane (ILM) separated the retina from the vitreous body (Fig. 3).

Examination of both control subgroups (Ia and $\mathrm{Ib}$ ) showed the same light microscopic results.

Examination of H\&E stained retinal sections of group II showed an apparent decrease in thickness of all retinal layers with disorganized outer and inner segments of photoreceptors compared to control group. The INL showed dilated blood vessels extending to the ONL. There was vacuolation of the GCL with the presence of congested blood vessels and some deeply stained nuclei (Fig. 4). By morphometric analysis, there was a significant decrease $(P<0.05)$ in both INL and ONL thickness in group II compared to both groups I and III (Table 1 and Histogram 2).

Examination of H\&E stained sections of group III showed apparent increase in the thickness of the retinal layers compared to group II. The outer and inner segments of photoreceptors appeared well organized. There were dilated and congested blood vessels in GCL as well as the INL and OPL. Migrating cells in the inner nuclear, inner plexiform and the inner and outer segments of rod and cone layer were observed (Fig. 5). By morphometric analysis, the increased thickness of outer and inner nuclear layers was significant $(P<0.05)$ (Table 1 and Histogram 2$)$.

The control group (group I) showed that the Glial fibrilary acidic protein (GFAP) immunohistochemical staining revealed negative immunoreactivity in the outer, inner nuclear layers. A positive immune reaction confined to astrocytes of the nerve fiber layer and GCL was detected (Fig. 6). The GFAB immunohistochemical staining of group II showed a positive immune reaction in the GCL and around its blood vessels with fine processes extending from the IPL toward the INL (Fig. 7). In addition, the GFAP immunohistochemical staining of group III revealed a positive immune reaction in the astrocytes of the internal limiting membrane, nerve fiber layer and around blood vessels in ganglion cell layer with fine processes extending up to the outer nuclear layer (Fig. 8). By morphometric analysis, there was a significant increase in GFAP positive immune reaction $(P<0.05)$ in group III as compared with group I (Table 1and Histogram 2).

\section{IV) Transmission electron microscope (TEM) examination}

The retinas of the control group showed that the RPE cells resting on Bruch's membrane and had basal rounded nuclei. Their cytoplasm contained basal mitochondria and small, spars dense bodies. The outer segments of photoreceptor cells were seen containing a stack of regularly arranged discs surrounded by a plasma membrane (Fig. 9).

The outer nuclear layer contained cell bodies of rod and cone cells. The predominant nuclei of rod cells showed highly condensed chromatin. Cone cells were also observed containing paler nuclei with coarse aggregations 
of chromatin lying peripherally close to the nuclear membrane (Fig. 10).

In the inner nuclear layer, horizontal cells appeared with large oval electron lucent nucleus. The nuclei of bipolar cells appeared rounded or elliptical in shape and surrounded by thin rim of cytoplasm. Muller cells contained nuclei of high density and showed numerous processes. Glial cells also appeared between the cells of INL with electron dense nucleus (Fig. 11). Ganglion cells showed large euchromatic nuclei with irregular nuclear envelope and prominent nucleoli. Their cytoplasm contained many mitochondria, smooth and rough endoplasmic reticulum (Fig. 12).

TEM examination of the retinas of group II showed that the pigment epithelial cells contained relatively many apical dense bodies and basal mitochondria. The microvilli appeared less organized than that of the control group (Fig. 13). The outer segments of photoreceptor cells appeared less organized with loss of normal orientation of its lamellar discs. Some discs showed vesicular changes (Fig 14). The nuclei of photoreceptors of the ONL showed wide spaces in between (Figs 15 and 16). Some rod cells appeared smaller with much condensed heterochromatin of their nuclei (Fig. 16).

Dilatation of the blood vessels was noticed in the
OPL. Multiple spaces were also seen in the INL (Fig 17). Ganglion cell layer showed some shrunken and electron dense nuclei. Most of the ganglion cells cytoplasm contained dilated endoplasmic reticulum and degeneratedmitochondria. The synaptic nerve terminals appeared dilated and vacuolated (Fig 18).

Examination of TEM sections of group III showed apparently normal retinal pigment epithelial cells nearly as that seen in control rats with few dense bodies, basal mitochondria and regular well organized microvilli (Fig. 19). Regularly arranged and numerous outer segments of photoreceptor cells with normal lamellar orientation of their discs were detected (Fig. 20). There was an apparent increase in the number of photoreceptor cells with no spaces in between the cells nearly similar to control (Fig 21). The INL contained many cells with irregular outline and euchromatic nucleus with peripheral heterochromatin (Figs 22). The GCL showed ganglion cells with euchromatic nuclei and prominent nucleoli. The cytoplasm of ganglion cells is rich in ribosomes, mitochondria and rough endoplasmic reticulum (Fig 23).

Labeled stem cells results: Injection of PKH26 labeled BMSCs into the vitreous body of eye of group III animals detected many labeled stem cells in the ONL, INL and in GCL of the retina (Fig 24)

Table 1: Showing the mean values $\pm \mathrm{SD}$ of the thickness of ONL and INL in $(\mu \mathrm{m})$ and the mean area percentage of GFAB positive immune reaction in different groups.

\begin{tabular}{lccc}
\hline Retinal measurements & Group I & Group II & Group III \\
\hline The thickness of ONL & $40.7 \pm 0.92$ & $16.8 \pm 0.83^{*}$ & $37.9 \pm 1.12^{\circ}$ \\
The thickness of INL & $31.6 \pm 0.61$ & $18.5 \pm 1.18^{*}$ & $30.7 \pm 2.18^{\circ}$ \\
GFAP +ve reaction & $2.4 \pm 0.79$ & $4.43 \pm 0.73$ - & $6.89 \pm 2.0^{\mathbf{\Delta}}$ \\
\hline
\end{tabular}

-Indicates a significant increase as compared with group II $(P<0.05),{ }^{*}$ Indicates a significant decrease as compared with control and group III $(P<0.05)$, Indicates a non significant increase as compared to control $(P>0.05), \boldsymbol{\Delta}$ Indicates a significant increase as compared to control $(P<0.05)$.
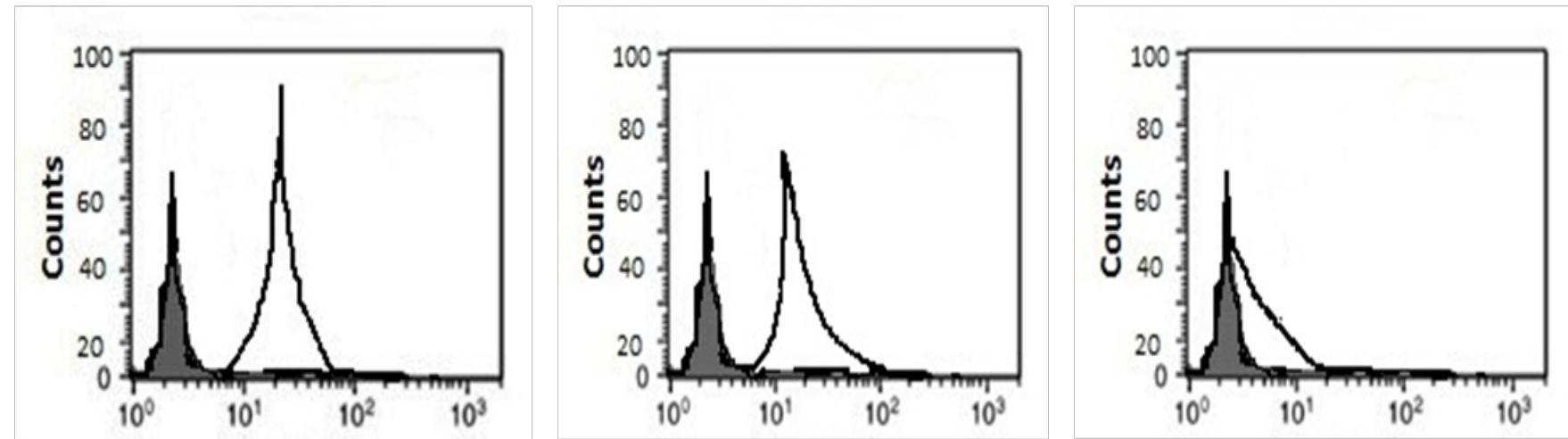

Histogram 1: Flowcytometric analysis of specific cell surface markers of rat BMSCs (1a) positive marker CD 29, (1b) positive marker CD 90 and (1c) negative marker CD34 


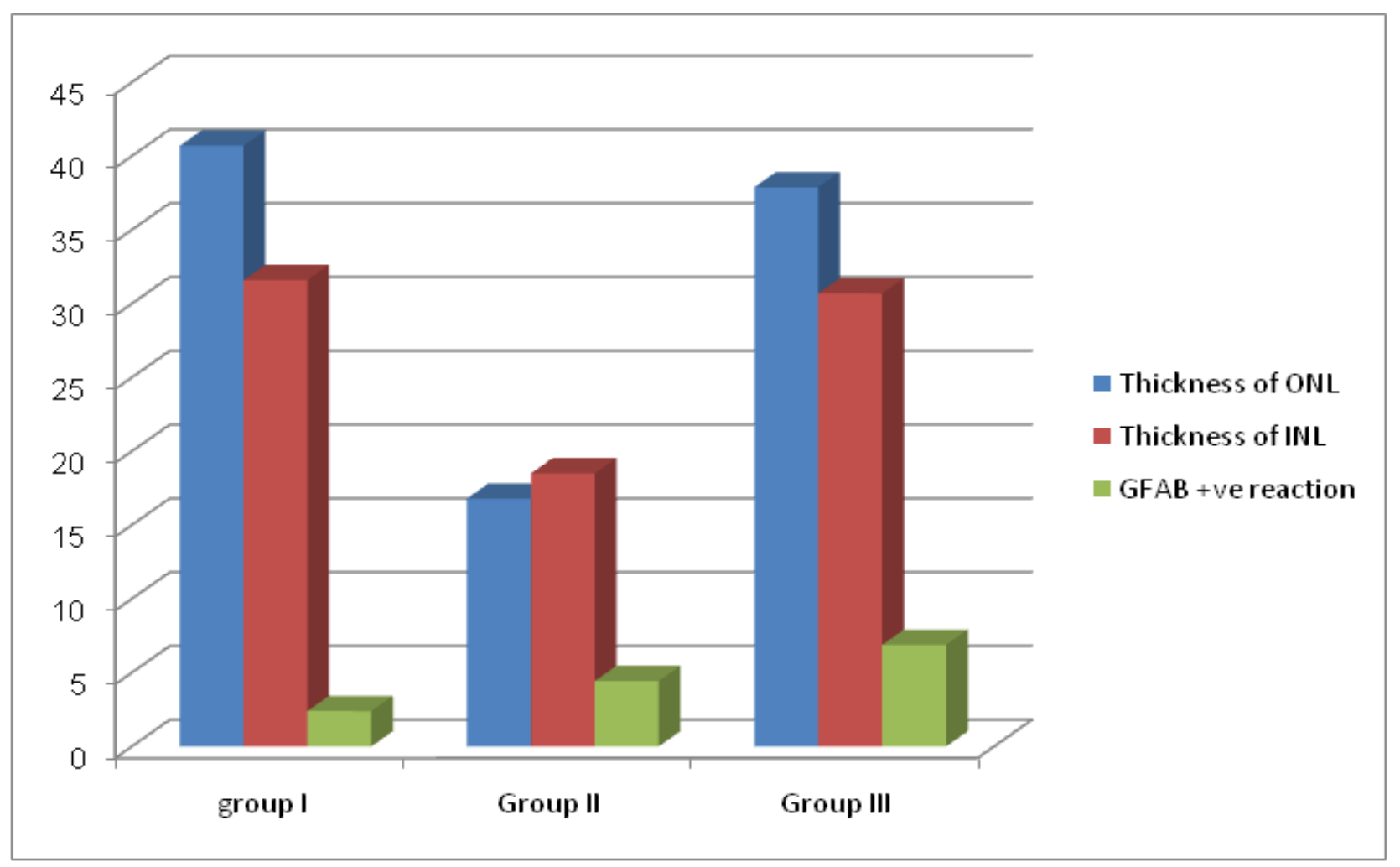

Histogram 2: Showing the mean values \pm SD of the thickness of ONL and INL in $(\mu \mathrm{m})$ and the mean area percentage of GFAB positive immune reaction in different groups

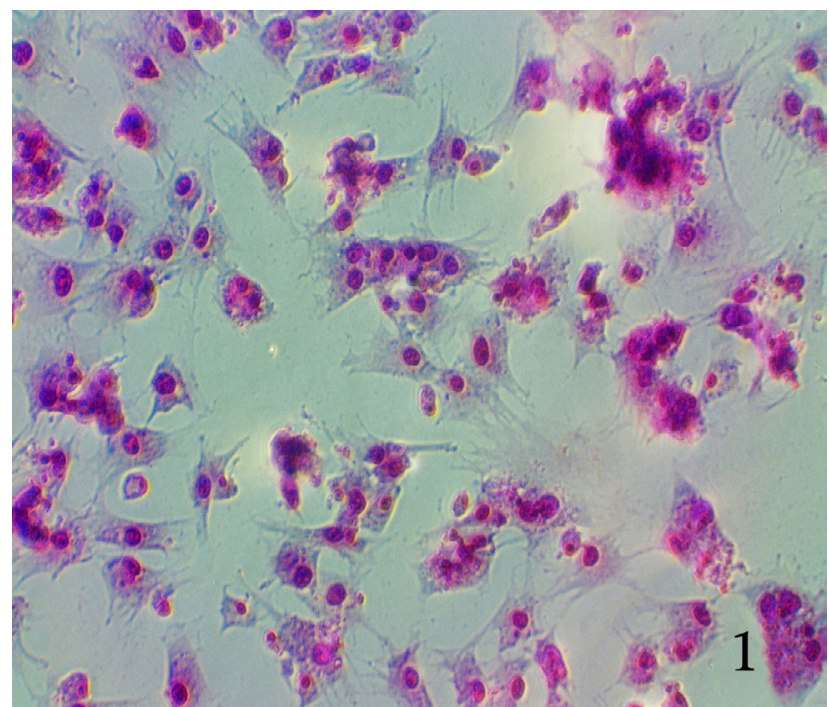

Fig 1: A phase contrast photomicrograph of seven days cultured rat BMSCs showing cells having bluish cytoplasm and vesicular nuclei.

(Giemsa stain x 200)

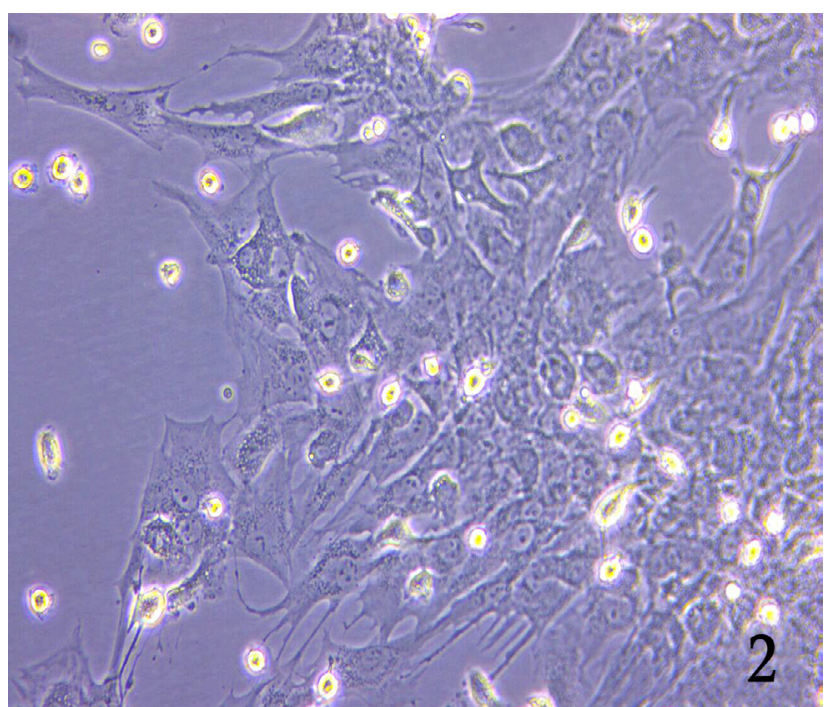

Fig. 2: A phase contrast photomicrograph five days after subculture of BMSCs showing spindle and star shaped cells with granular cytoplasm and vesicular nuclei.

(phase contrast microscope x200) 


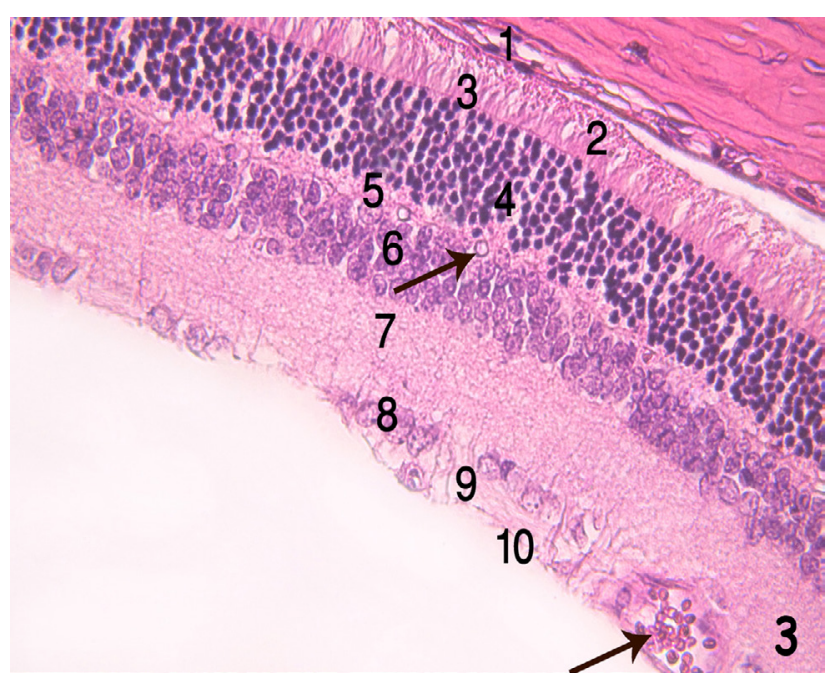

Fig. 3: A photomicrograph of a section of a rat retina of group I showing the ten layers of the retina : pigment epithelial cells (1), the outer segments of rods and cones (2), the outer limiting membrane (3), the outer nuclear layer (4), the outer plexiform layer (5), the inner nuclear layer (6), the inner plexiform layer (7), the ganglion cell layer (8), nerve fiber layer (9) and the inner limiting membrane (10). Note the blood vessels $(\uparrow)$ in layers number 5 and 9 .

$(\mathrm{H} \& \mathrm{E} \times 400)$

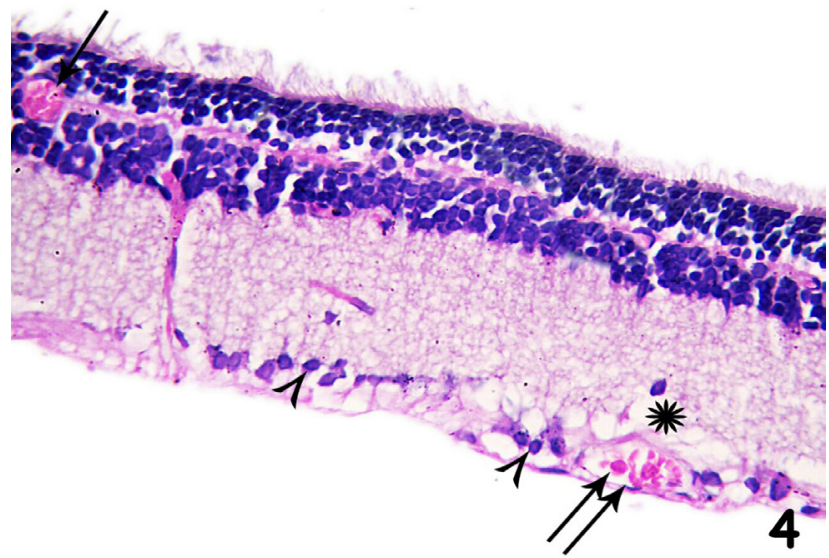

Fig. 4: A photomicrograph of a section in a rat retina of group II showing disorganized outer and inner segments of photoreceptors. There are spaces, disorganization with an apparent decrease in the thickness of the ONL. Notice the dilated blood vessels $(\uparrow)$ in INL that extend to ONL. There is also cytoplasmic vacuolation of the GCL $(*)$ around a congested blood vessel $(\uparrow \uparrow)$ and some cells had deeply stained nuclei $(<)$.

$(\mathrm{H} \& \mathrm{E} x 400)$

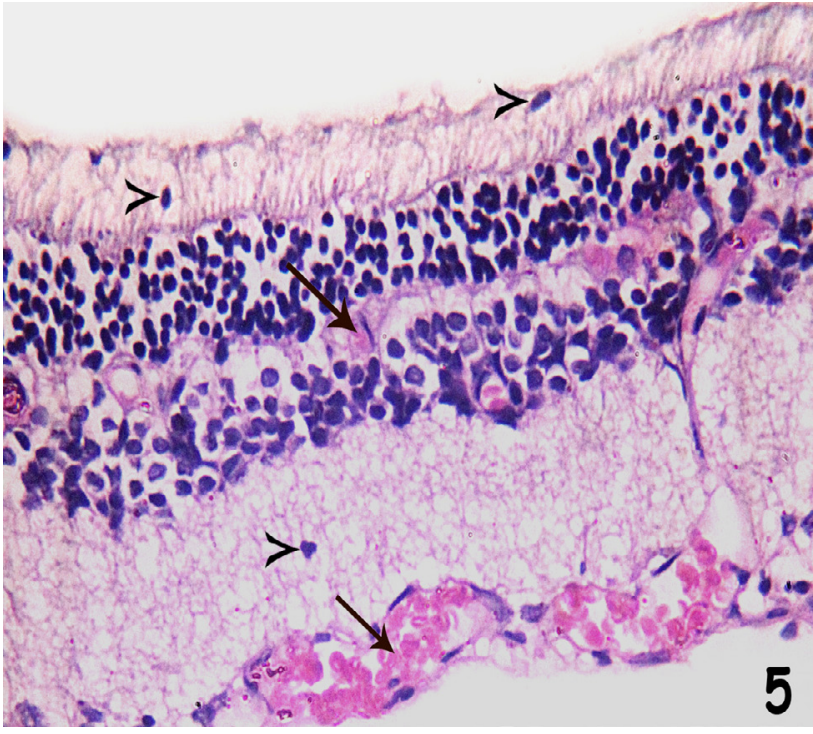

Fig. 5: A photomicrograph of a section in a rat retina of group III showing an apparent increase in the thickness of the retinal layers. There are dilated and congested blood vessels in INL, OPL and GCL ( $\uparrow)$. Note the presence of some cells in between outer and inner segments of photoreceptors as well as in inner plexiform layer $(<)$

$(\mathrm{H} \& \mathrm{E} \times 400)$

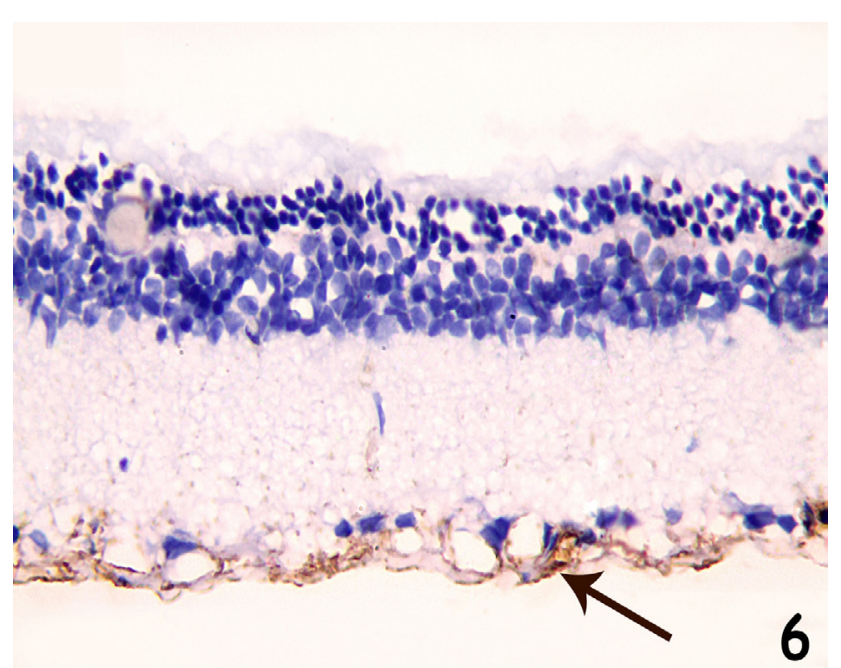

Fig. 6: A photomicrograph of a section in a rat retina of group I showing positive GFAP immune reaction for astrocytes of ganglion cell layer and nerve fiber layer $(\uparrow)$.

(Streptavidin-biotin peroxidase $\mathrm{x} 400$ ) 


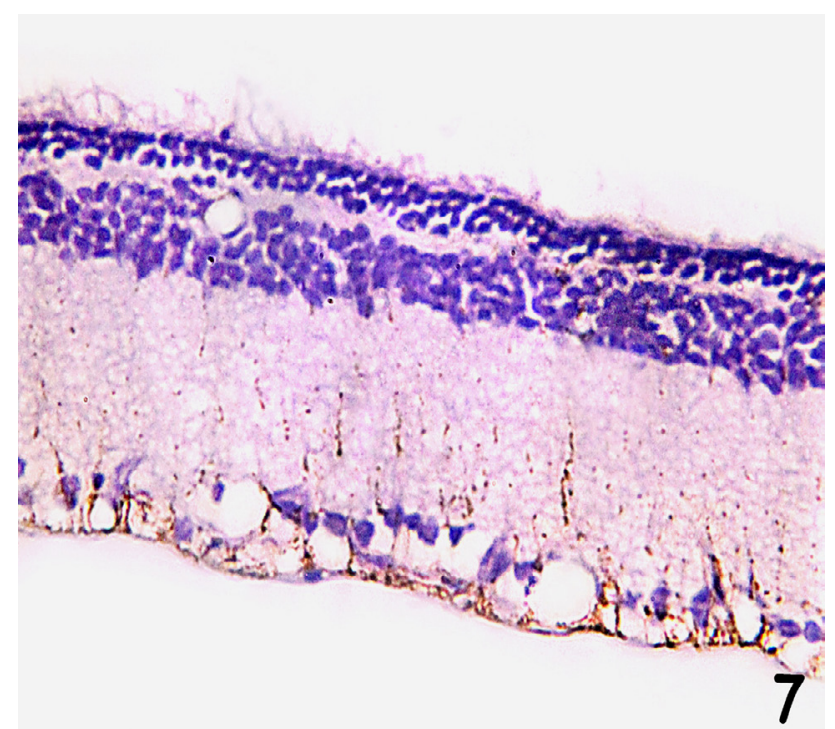

Fig. 7: A photomicrograph of a section in a rat retina of group II showing a positive GFAP immune reaction in the GCL and around its blood vessels with fine processes extending in the IPL. (Streptavidin-biotin peroxidase $\mathrm{x} 400$ )

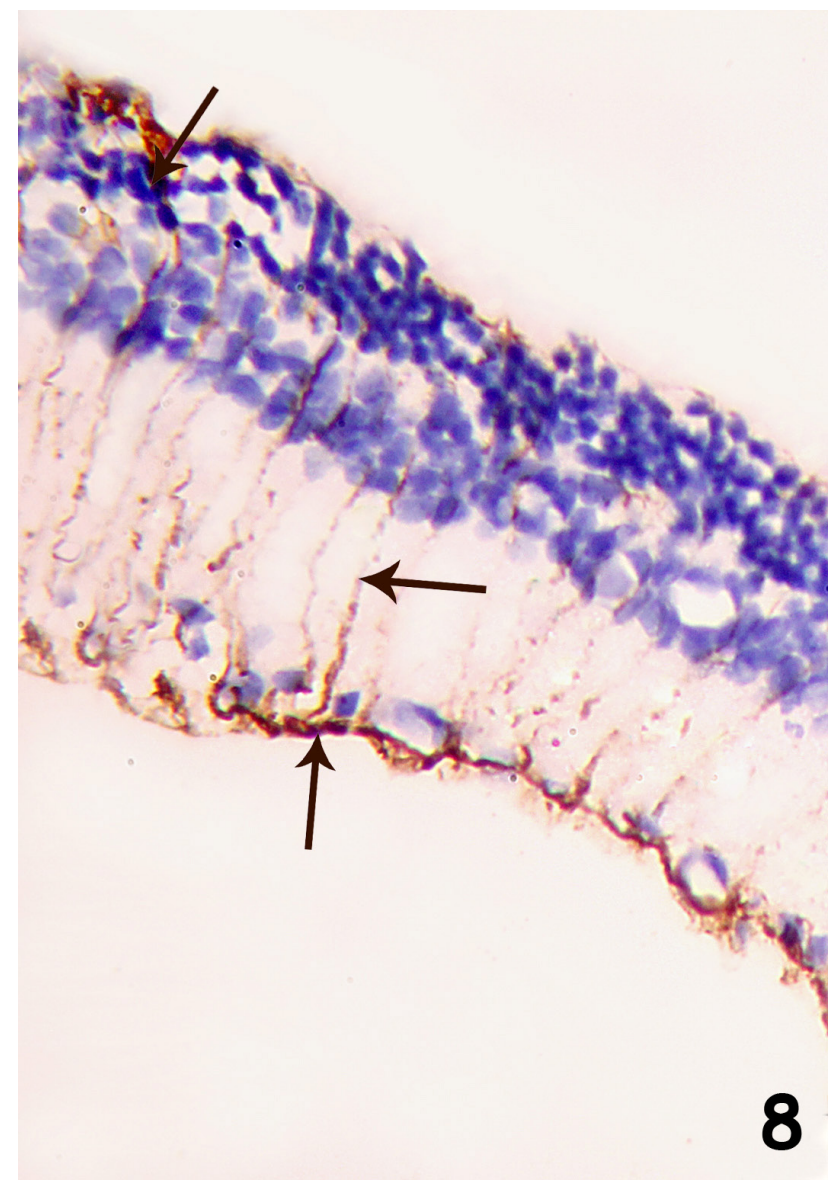

Fig. 8: A photomicrograph of a section in a rat retina of group III showing positive GFAP immune reaction in the ILM and NFL with many processes extending up to the ONL $(\uparrow)$.

(Streptavidin-biotin peroxidase $\mathrm{x} 400$ )

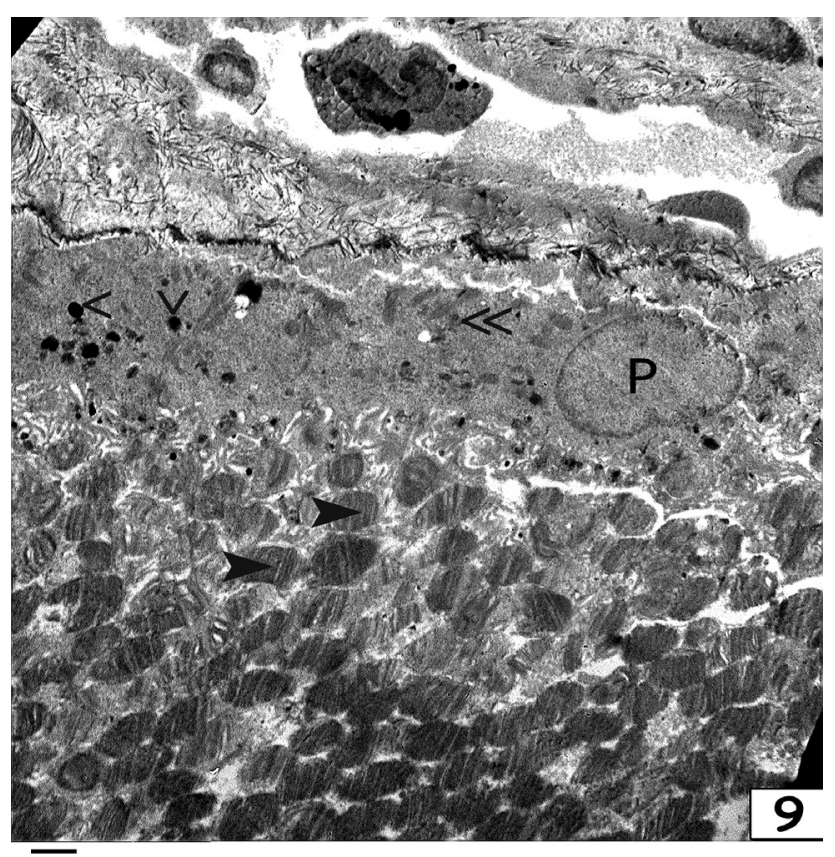

$\overline{2 \text { microns }}$
TFM Mag $=4000 x$

Fig. 9: Electron micrograph of group I showing retinal pigment epithelium (P) rests on Bruch's membrane (B). The cell contains basal mitochondria (») and few dense bodies (〉). The outer segments of photoreceptor cells $(\mathbf{\Delta})$ appear with regularly arranged lamellar discs.

(TEM x4000)

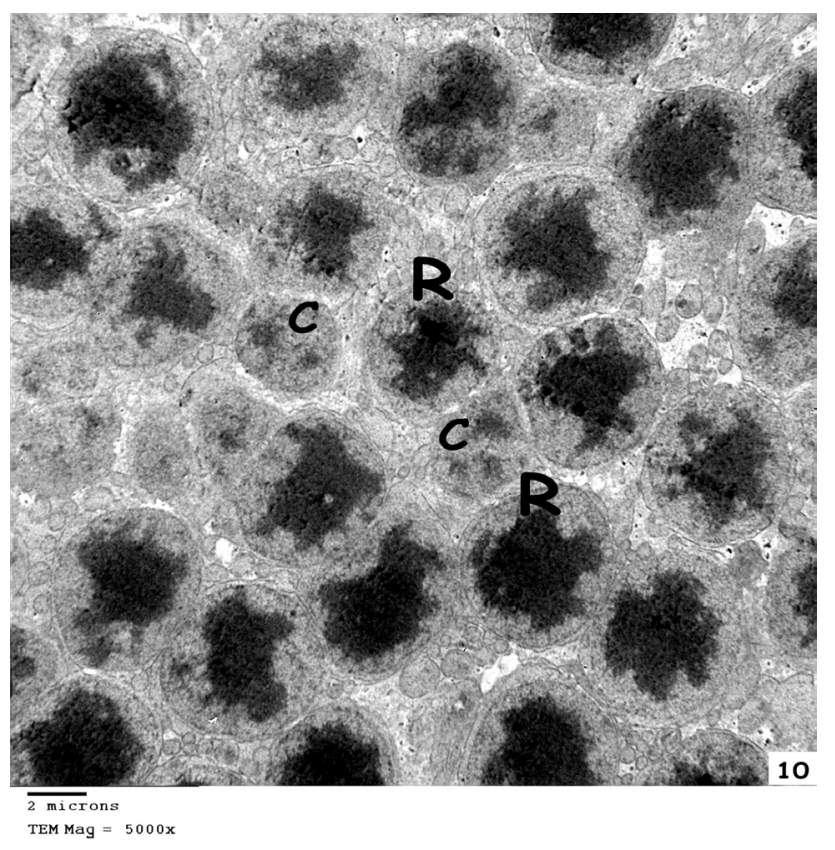

Fig. 10: Electron micrograph of group I showing the rod and cone cells of the outer nuclear layer. Rod cells (R) nuclei have central condensed heterochromatin while cone cells (C) nuclei are lighter with coarse chromatin lying peripherally

(TEM x5000) 


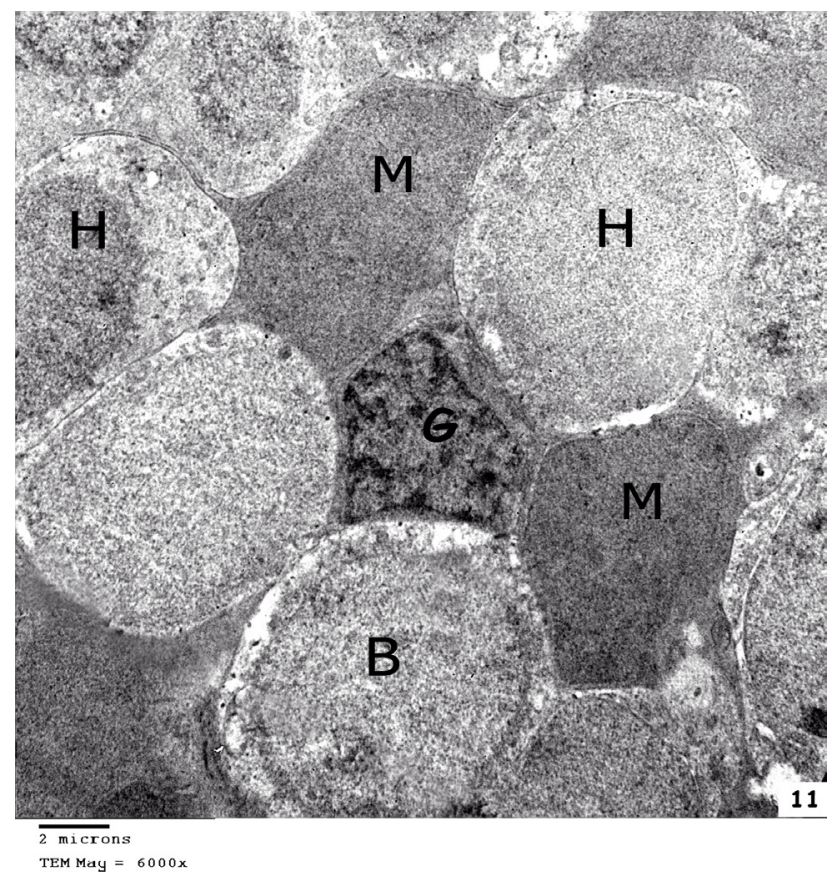

Fig. 11: Electron micrograph of group I showing IN L containing bipolar cells (B). Muller cells (M) with multiple processes, horizontal cell $(\mathrm{H})$ and glial $(\mathrm{G})$ cell.

$($ TEM $\times 6000)$

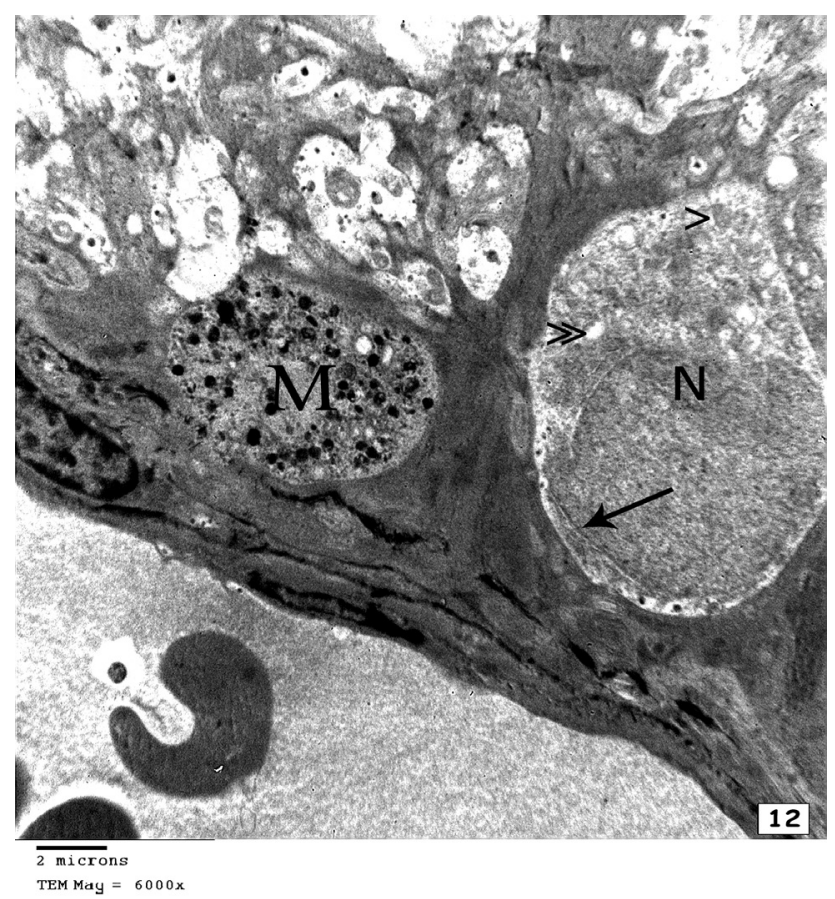

Fig. 12: Electron micrograph of group I showing a ganglionic cell having large euchromatic nucleus $(\mathrm{N})$ and irregular nuclear envelop ( $\uparrow)$. Its cytoplasm contains mitochondria ( $)$ and SER («). A microglia cell $(\mathrm{M})$ containing many lysosomes appears beside the ganglion cells.

$($ TEM $\times 6000)$

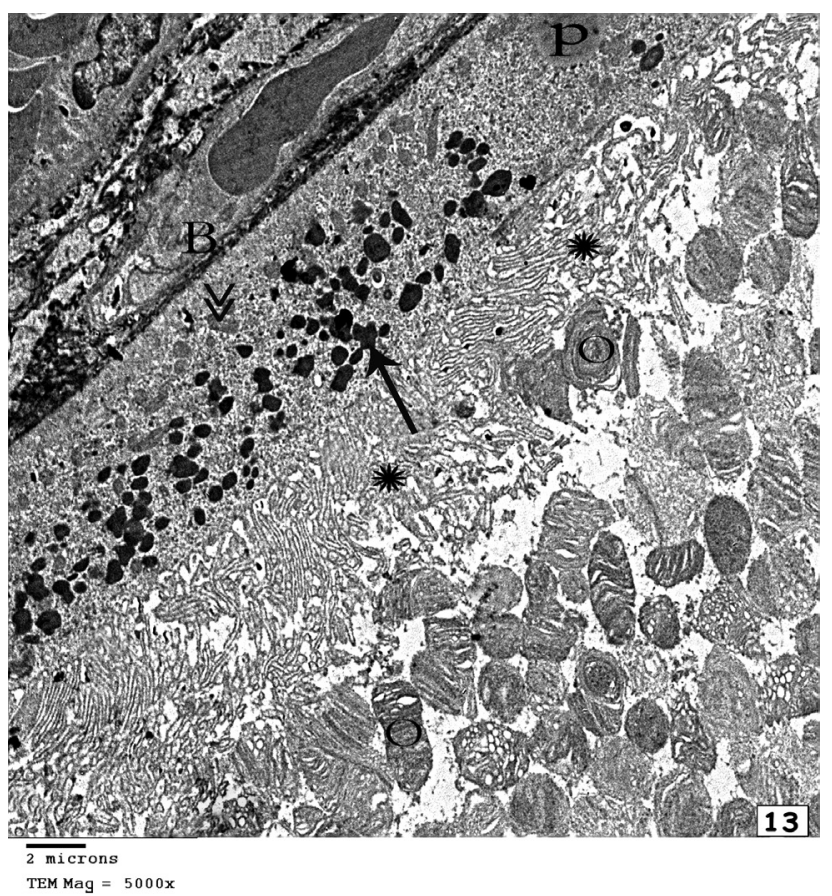

Fig. 13: Electron micrograph of group II showing the pigment epithelial cells (P) resting on Bruch's membrane (B) with basal mitochondria ( $\ll$ ) and many apical dense bodies $(\uparrow)$. The microvilli $(*)$ and the discs of outer segments $(\mathrm{O})$ of photoreceptor cells appear disorganized.

(TEM x5000)

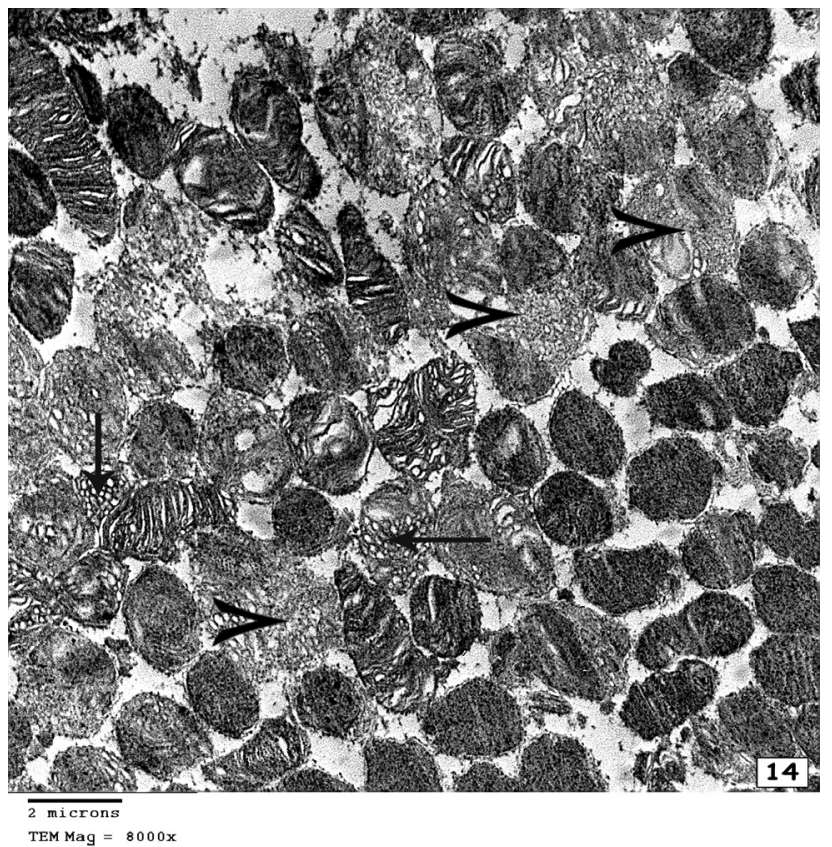

Fig. 14: Electron micrograph of group II showing the outer segments of photoreceptors appear disorganized with loss of normal orientation of its lamellar discs (>). Some show vesicular changes $(\uparrow)$.

$(\mathrm{TEMx} 8000)$ 


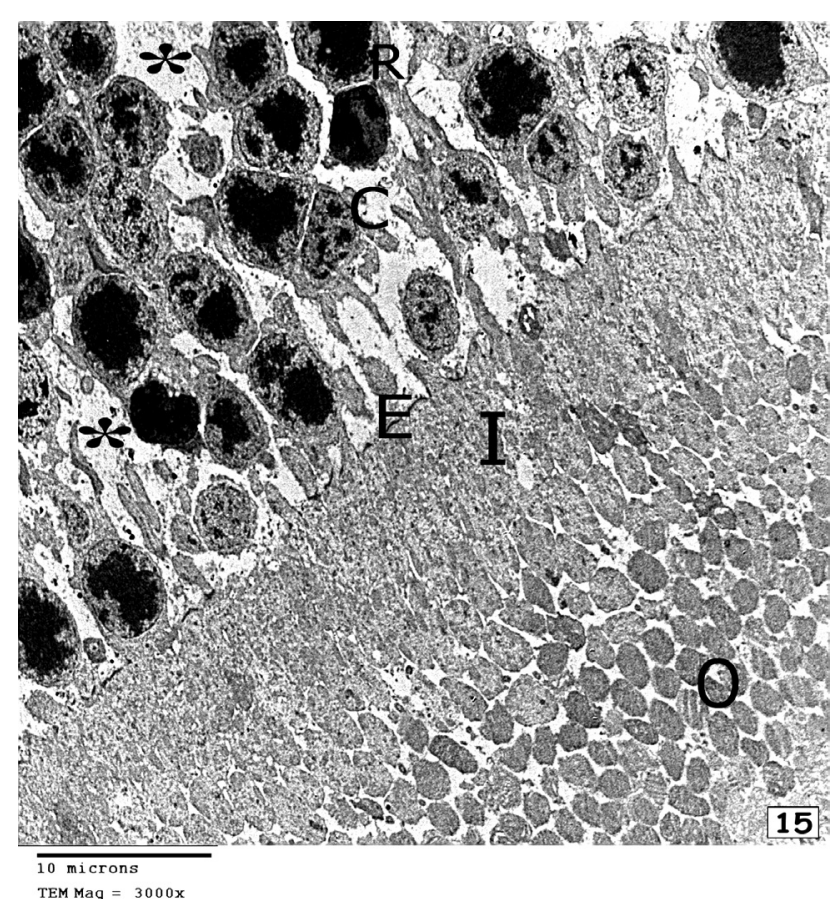

Fig. 15: Electron micrograph of group II showing the outer $(\mathrm{O})$, inner (I) segments of photoreceptor cells and the external limiting membrane (E). The rod (R) and cone (C) nuclei in the ONL appear with wide spaces in between $\left(^{*}\right)$.

(TEM x3000)

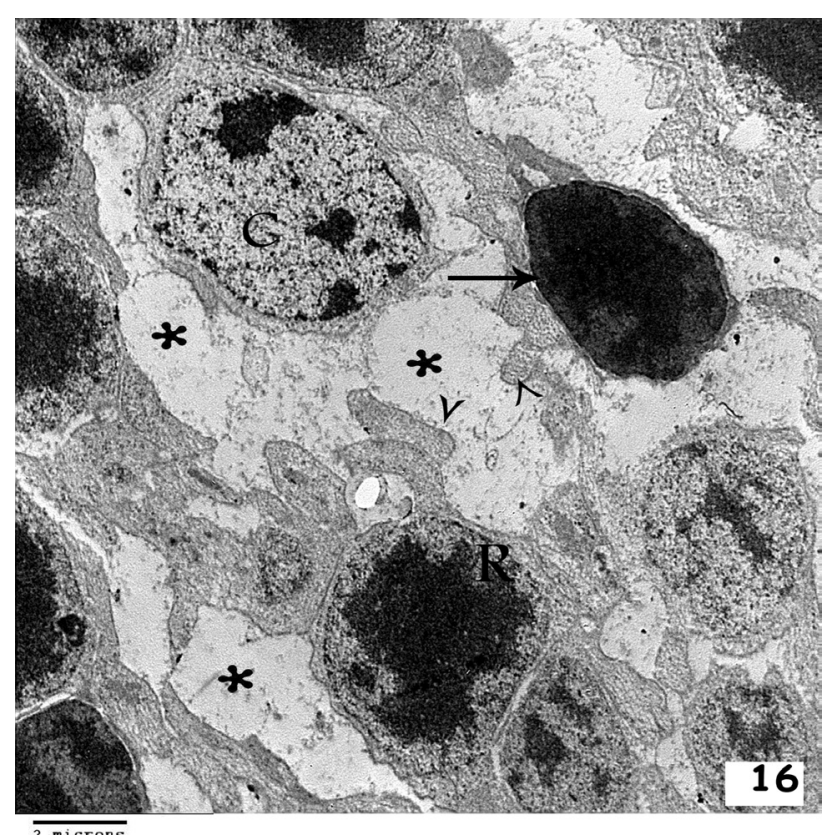

2 microns

Fig. 16: Electron micrograph of group II showing the cone (C) and $\operatorname{rod}(\mathrm{R})$ photoreceptor cell nuclei surrounded with cellular processes $(<)$. Some rod cells appear smaller with condensed heterochromatin $(\uparrow)$ in their nuclei. Notice many wide spaces appear in between the cells $(*)$.

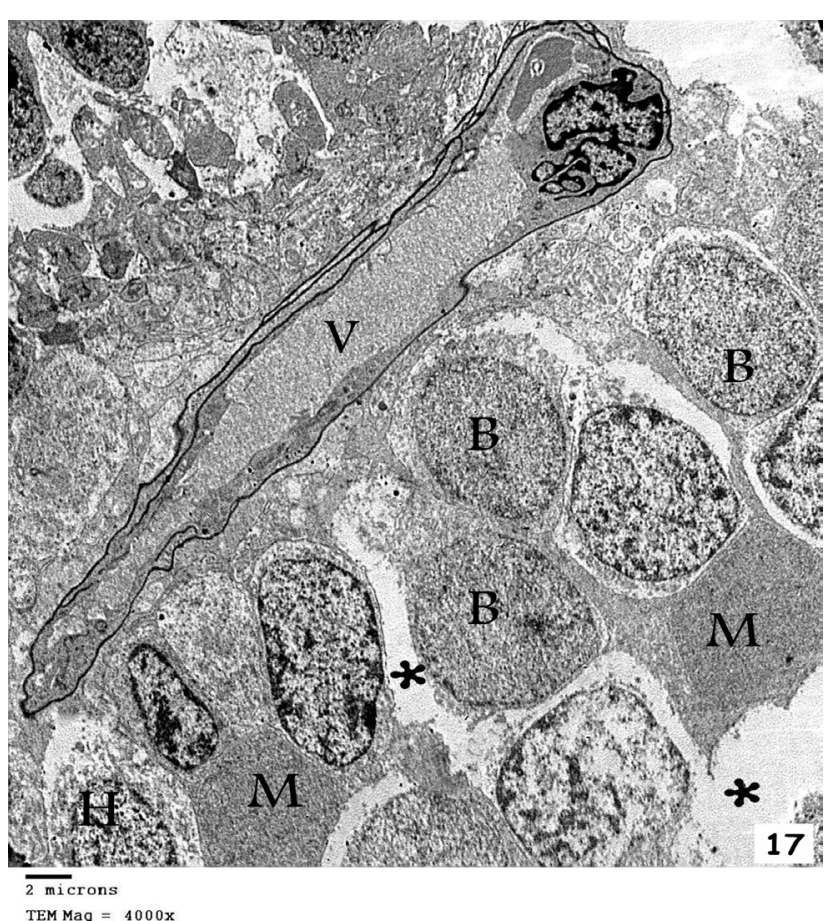

Fig. 17: Electron micrograph of group II showing the OPL containing a dilated blood vessel (V). The INL contains bipolar (B), Muller (M) and horizontal $(\mathrm{H})$ cells. Notice the wide spaces in between the cells $(*)$.

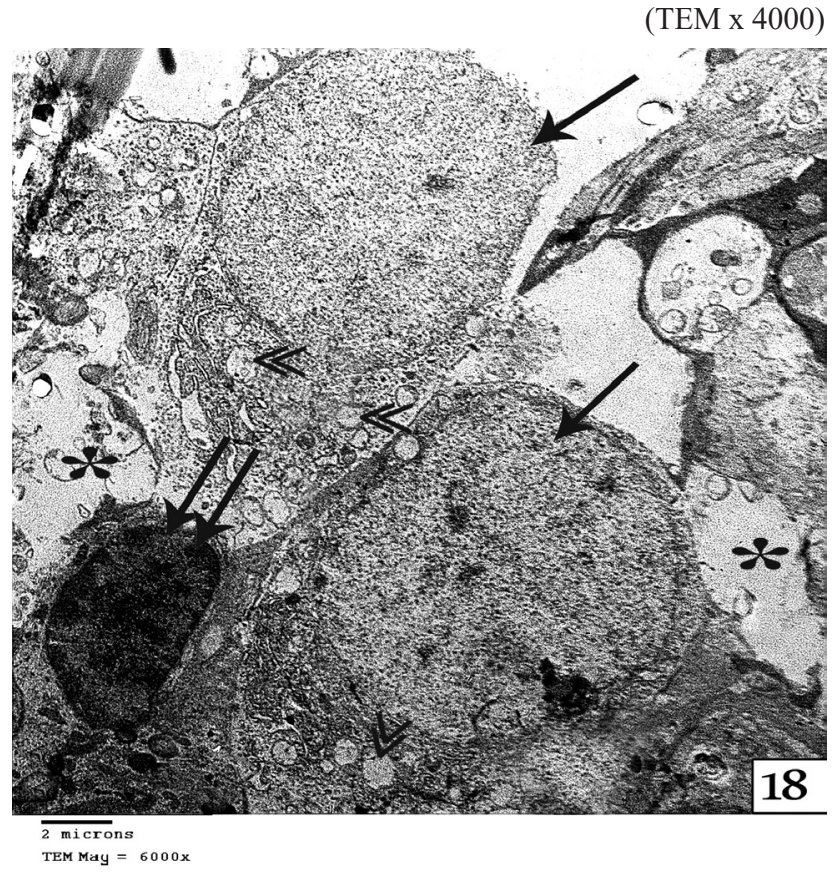

Fig. 18: Electron micrograph of group II showing ganglion cells with euchromatic nucleus $(\uparrow)$. The cytoplasm of the cells contain dilated rough endoplasmic reticulum, degenerated mitochondria ( ) and many dilated smooth endoplasmic reticulum («). An electron dense and shrunken nucleus is observed $(\uparrow \uparrow)$. Notice the distorted synaptic nerve terminals $(*)$.

(TEM $\mathrm{x} 8000)$ 


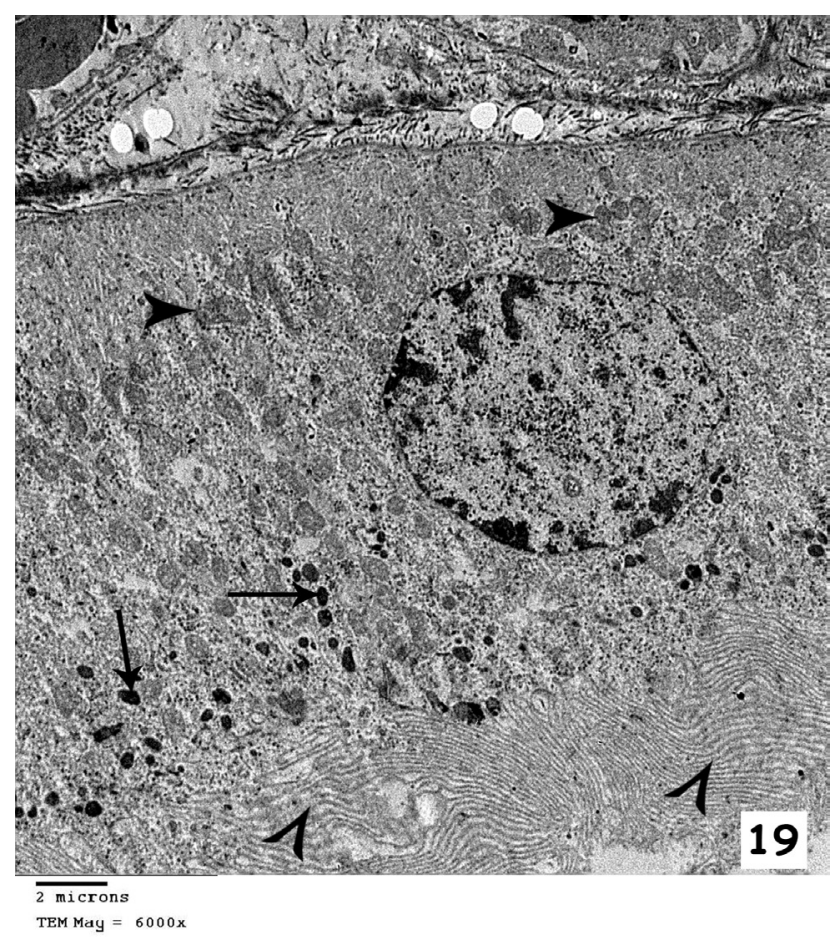

Fig. 19: Electron micrograph of group III showing the pigment cell with scattered apical dense bodies $(\uparrow)$ and many mitochondria $(\boldsymbol{\Delta})$. Note many well defined microvilli $(<)$.

(TEM $\times$ 6000)

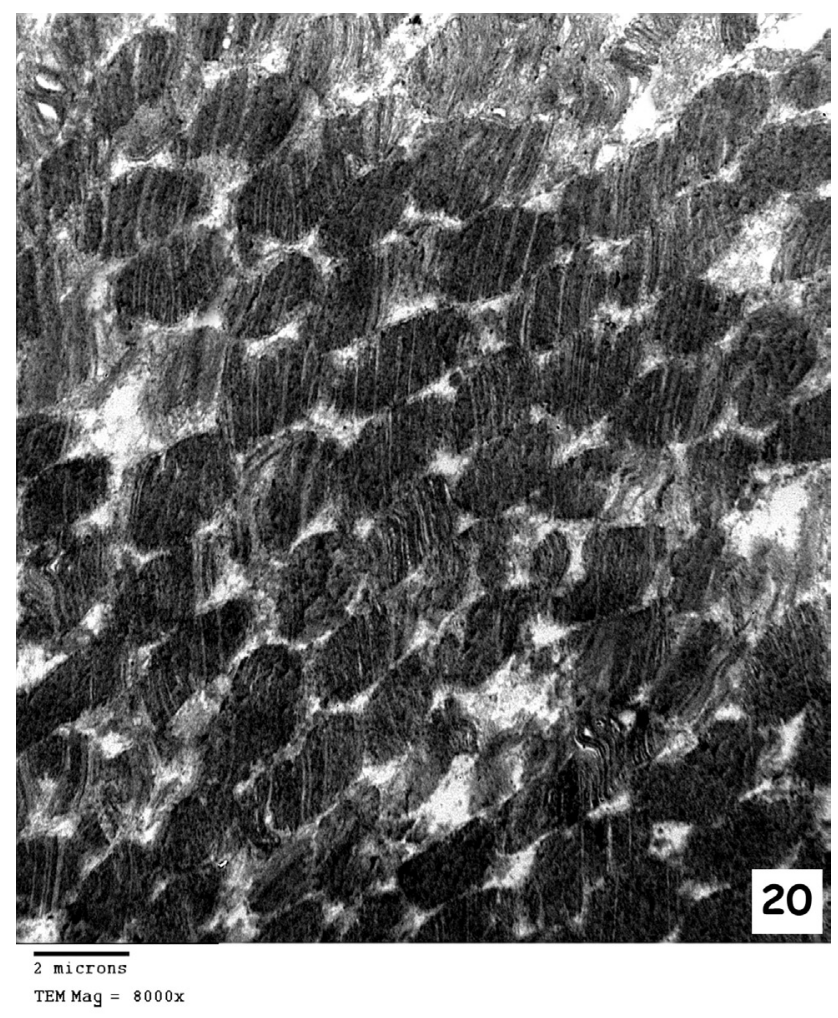

Fig. 20: Electron micrograph of group III showing the outer segments of photoreceptors. They appear with regularly arranged lamellar discs.

(TEM x8000)

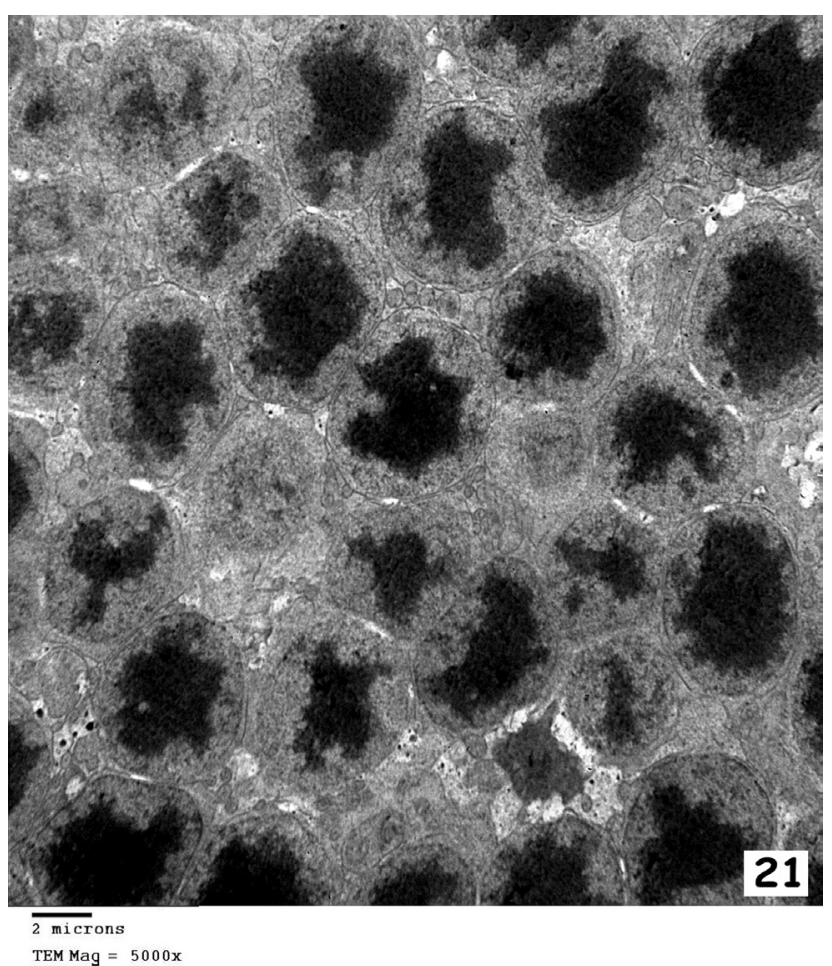

Fig. 21: Electron micrograph of group III showing an apparent increase in the number of photoreceptor cells with no spaces in between.

(TEM $\times 5000)$

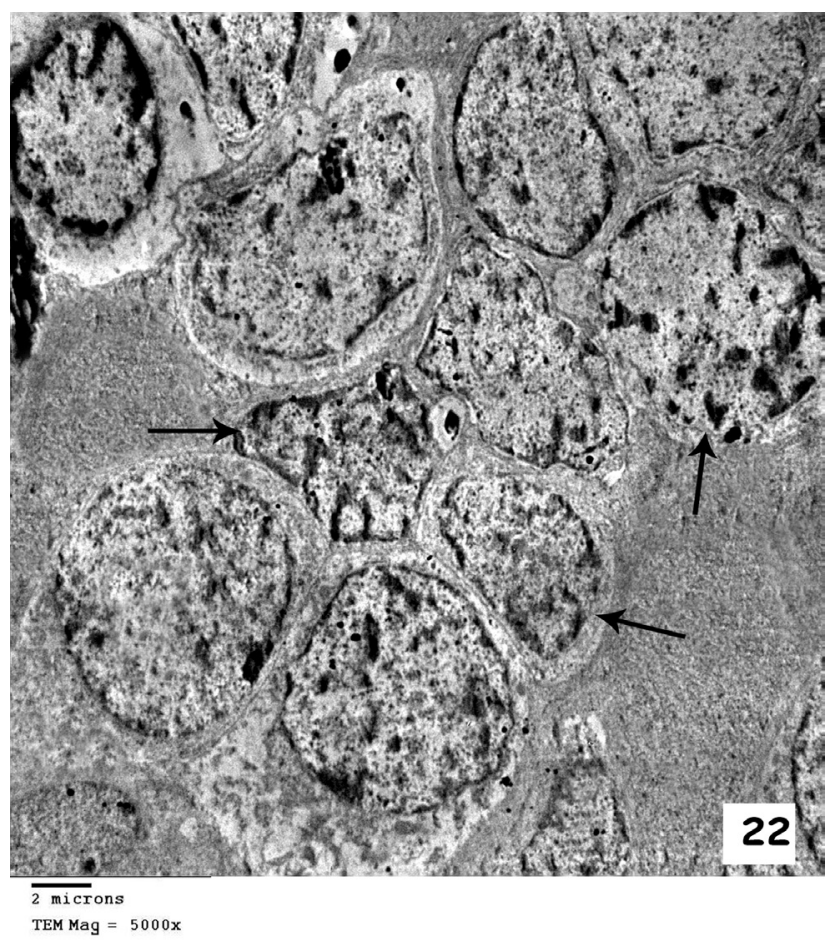

Fig. 22: Electron micrograph of group III showing the inner nuclear layer containing many cells with irregular outline and their nuclei appear with peripheral heterochromatin $(\uparrow)$.

(TEM x 5000) 


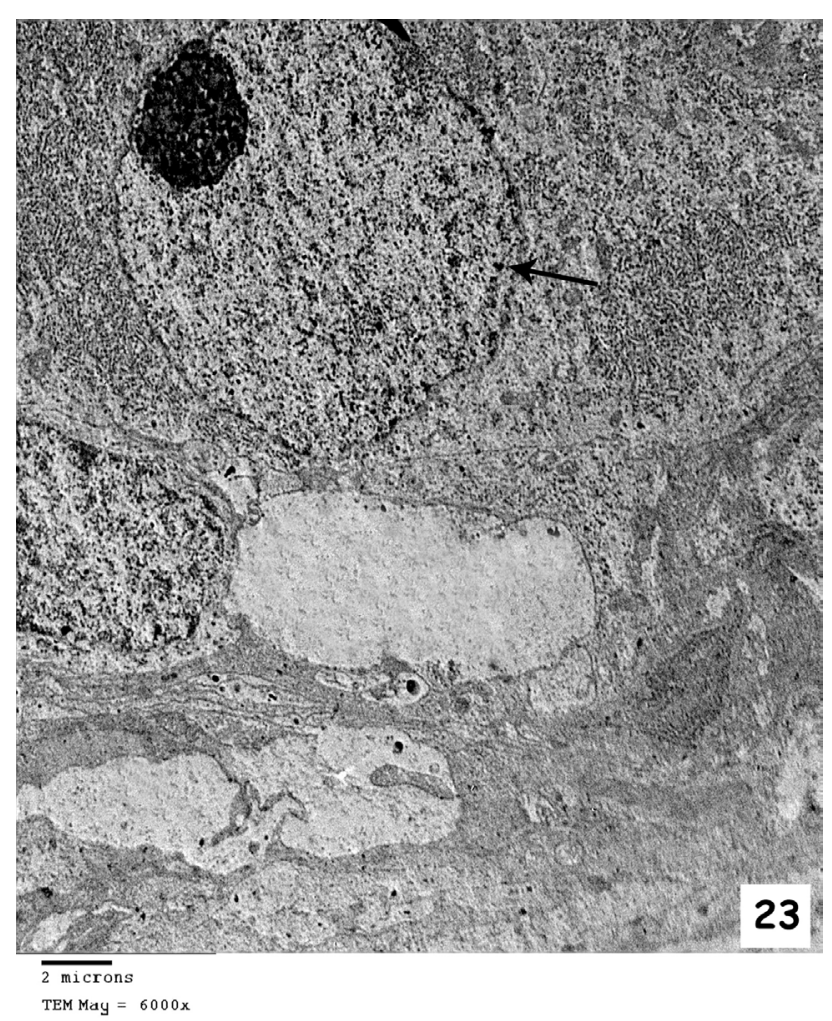

Fig. 23: Electron micrograph of group III showing a large ganglion cell with euchromatic nucleus and prominent nucleolus ( $\uparrow$. The cytoplasm contains many ribosomes, mitochondria and rER.

(TEM x 6000)

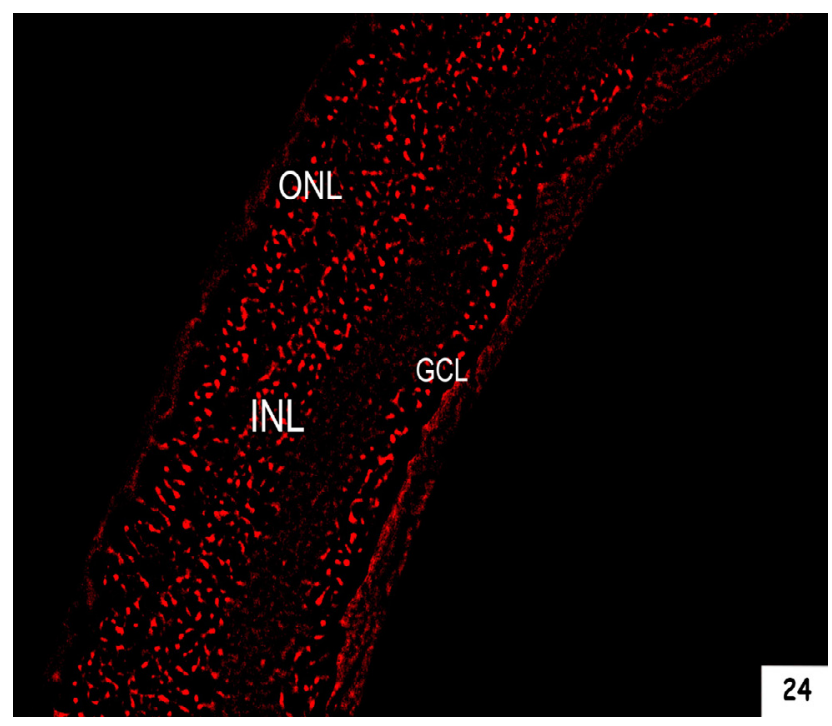

Fig. 24: Fluorescence micrograph of group III showing positive PKH 26 labelled stem cells scattered in ONL, INL and GCL.

(Fluorescent microscope x200)

\section{DISCUSSION}

Blindness can result from a number of inherited retinal and retinal-neuronal degenerative diseases, such as retinitis pigmentosa and age related macular degeneration ${ }^{[1]}$. Besides, light can also affect the photoreceptors and lead to its degeneration ${ }^{[3]}$. We used light damage as a model of retinal degeneration. Current therapies can slow progression, but cannot restore lost neurons or vision. Thus, Stem cell based therapy is a hope in the strategies for therapeutic retinal regeneration.

This study revealed that continuous fluorescent light exposure of albino rats caused retinal degeneration and apoptosis of the photoreceptors. Previous immunohistochemical study suggested that oxidative stress was the cru $\neg$ cial risk factor for photoreceptor degeneration. This was evidenced by the toxic reactive oxygen species gen $\neg$ erated in the retina after light exposure. This suggested that light- induced cell death occurred through the intrinsic apoptotic pathway under oxidative stress ${ }^{[3]}$. Retinal degeneration might be attributed to the sensitivity of the retina to oxidative stress as it is one of the tissues that have highest oxygen consumption levels in the body ${ }^{[15]}$. Moreover, it was proved that continuous light exposure of the retinal tissue generated free radicals and reactive oxygen species. These products caused damage of the photoreceptors and other retinal tissues ${ }^{[16]}$.

In the present work, apoptosis and nuclear changes in the inner nuclear and outer nuclear layers were detected by light microscopic and TEM examination. It appeared in the form of spacing, nuclear chromatin condensation and pyknosis. Similar findings had been previously reported and proved by presence of TUNEL-positive nuclei in the inner nuclear layer, ONL and also in the ganglion cell layer of the retina of Albino rats ${ }^{[3 \text { and } 11]}$.

In the current study, the ganglion cells (GCs) were also affected in the fluorescent light exposure group. Many GC had deeply stained nuclei with vacuolated cytoplasm and distorted organelles. It was revealed that retinal ganglion cells are responsible for detecting light and suppressing melatonin production and these cells are most sensitive to blue/violet light ${ }^{[17]}$. This was explained by some authors as when light enters the eye, it interacts with the mitochondria in ganglion cell axons and produce reactive oxygen species (ROS) that causes DNA damage by means of the intrinsic apoptotic pathway ${ }^{[18]}$. Thus ganglion cells are susceptible to damage particularly as they are present in the most internal layer and their axons are rich in mitochondria.

On the other hand, in this research distorted outer and inner segments of photoreceptors were detected after fluorescent light damage in group II and the thickness of ONL significantly decreased compared to other groups. 
This came in agreement with a previous study that demonstrating shortening of the outer and inner segments of most photoreceptors and even vanished gradually after light injury. The number of ONL cells was decreased and apoptosis of photoreceptors also occurred as time went on. These results were supported by TUNEL staining and statistical analysis ${ }^{[19]}$.

Moreover, in group II alteration of the retinal pigment epithelial cells occurred in the form of increase in dense bodies and distorted microvilli. These finding can be explained by a previous work mentioned that the retinal pigmented epithelial cells maintained the health of photoreceptors by recycling photopigments, metabolizing, storing vitamin A and phagocytosing shed photoreceptor segments ${ }^{[20}$ and 21$]$. Moreover, it was proved that degeneration of RPE was related to oxidative stress as it contains antioxidant enzymes involved in detoxification or synthesis ${ }^{[22]}$.

In addition, the atrophic or degenerative retinal diseases, genetic and environmental factors led to immune mediated oxidative stresses that had compromised the retinal pigment epithelium ${ }^{[23]}$.

The degenerative changes in retina continued for 8 weeks after light exposure in group II was consistent with Wasowicz et al. 2002 who focused on the long-term continuation of morphologic and biochemical damages 11 weeks after exposure ${ }^{[11]}$. They proved that phototoxicity provoked durable retinal alterations beyond the period of lighting, suggesting progressive and probably continuous modifications of retinal physiology.

The light and electron microscopic examination of group II revealed increase in the number of Muller cells with more extensive processes as demonstrated by GFAP immune reaction. Alike, Marc and colleagues, 2008 considered reactive gliosis in Muller cells as a sign of remodeling in response to a wide variety of ocular conditions; among them is light damage ${ }^{[24]}$. Reactive gliosis is a cytological alteration involving Muller cells affecting its axons and processes. They appeared as a classical astrocytic scar.

The photoreceptors degeneration and loss can be attributed to presence of toll like receptors (TLRs) ${ }^{[25]}$. Moreover, some authors found that TLR4 activation caused photoreceptor death due to oxidative stress in vivo and in vitro ${ }^{[26 \text { and } 27]}$.

For their advantages of; easy isolation and good culture properties and their high expansion potential made them an ideal source for transplantation and a cell-based therapy for retinal degeneration ${ }^{[4]}$, BMSCs were used to repair damaged retina in group III.. In addition, BMSCs secrete various neurotrophic factors that activate compensatory processes in abnormal tissues ${ }^{[28,29]}$. Also, BMSCs produce several matrix molecules and have a great potential to repair damage resulting from injury, ischemia, and normal $\operatorname{aging}^{[30]}$.
Meanwhile, it was demonstrated that BMSCs had a vasculotrophic and neurotrophic effects and rescued retinal blood vessels when injected intravitreally into mice with retinal degenerative disease ${ }^{[31]}$. Moreover, BMSCs from adult human donors are safe and well-tolerated when administered intravitreally up to a dose of $15 \times 10^{6}$ cells $/ \mathrm{ml}$ in rabbits ${ }^{[10]}$.

In the present study, the preferred route of administration of BMSCs was the intravitreal route rather than subretinal one. Similarly, Castanheira et al. 2008demonstrated that the subretinal implantation of stem cells was a more demanding and complex procedure while the intravitreal injection was a more popular and a much less invasive procedure $^{[12]}$.

In the present work, PKH26 labelled BMSCs were injected into the vitreous cavity in group III. The PKH26 labelled BMSCs were detected by fluorescent microscope in the ONL, INL and GCL in group III with less spaces and significant increase in the thickness of ONL and INL. Alike, Castanheira et al. 2008 detected BM-MSCs in the ONL, INL, and the GCL after intravitreal injection ${ }^{[12]}$. Whereas the MSCs were not only incorporated in the retinal tissue but also differentiated into specific cellular components. Some MSCs were differentiated into cells that resembled microglia rather than neural cells.

Moreover, it was reported that after retinal injury, the animals treated with BMSCs transplantation had significantly a smaller percentage of apoptotic ONL cells than did the light damage animals. The authors attributed the rescue effects observed after BMSCs transplantation to the trophic effects of BMSCs and not to its differentiation to neural cells ${ }^{[19]}$. In addition, it was proved that BMSCs had the capacity to produce some kinds of trophic factors in the light-damaged model eye. These neurotrophic factors caused inhibition of the photoreceptor apoptosis ${ }^{[32-34]}$.

The current study revealed improvement in the stem cells treated group. There was significant increase in the thickness of all layers. TEM examination revealed decrease in the degenerative features. The retinal pigment epithelial cells regained. The outer and inner segments of photoreceptors became more organized and longer. Less apoptosis and few spaces were detected in the photoreceptor layers. Most ganglion cells appeared nearly normal. There was also increase in GFAP positive immune reaction. These results were supported by previous studies demonstrating that intravitreally injected BMSCs could help in amelioration and repair of the retinopathy through their incorporation into the retina as endothelial cells, microglia, and photoreceptors (35-37). In addition, it was proved by staining with antibody against rhodopsin that epiretinal transplantation of BMSCs preserved rod photoreceptor cell structure for up to 20 weeks. The ONL showed more layers of cells following stem cell transplantation ${ }^{[38]}$.

In group III, we detected an increase in GFAP positive reaction attributed to the labeled BMSCs differentiated 
into glial cells expressing GFAP ${ }^{[39]}$. Noteworthy, astrocytes which surround blood vessels usually participate in the response to injury by formation of synapses, help in the phagocytic removal of unwanted synapses, and in neurotransmitter recycling ${ }^{[41]}$.

Interestingly, Müller cells, which are the primary source of new neurons, are therefore considered as the cellular basis for retinal regeneration in mammalian retinas. Besides, Müller stem cells might play regenerative role in retinal repair and replacement ${ }^{[42]}$.

\section{CONCLUSION}

Intravitreal injection of BMSCs could ameliorate retinal degeneration resulted from continuous fluorescent light exposure.

\section{RECOMMENDATIONS}

- The results of the present study might be clinically applied for the treatment of incurable retinal degenerative diseases.

- Stem cells therapy might represent a promising new therapeutic strategy that assists the repair of the damaged retinas.

- Much effort has to be exerted to enhance the differentiation of the stem cells to neural retinal cells. Addition of specific growth factors might lead to hopeful results.

- Induced pluripotent stem cells (IPSCs) also might be used to avoid immune rejection reactions.

\section{CONFLICT OF INTEREST}

There are no conflicts of interest.

\section{REFERENCES}

1. Wong WL, Su X, Li X, Cheung CM, Klein R, Cheng CY, Wong TY. Global prevalence of agerelated macular degeneration and disease burden projection for 2020 and 2040: A systematic review and meta-analysis. Lancet Glob Health 2014; 2: 106-116.

2. Cachafeir $\mathrm{M}$, Bemelmans $\mathrm{AB}$, Samardzija M, Afanasieva T, Pournaras JA, Grimm C, Kostic C, Philippe1S, Wenzel A, Arsenijevic Y. Hyperactivation of retina by light in mice leads to photoreceptor cell death mediated by VEGF and retinal pigment epithelium permeability. Cell Death and Disease 2013; 4(e781): 1-11.

3. Shang YM, Wang GS, Sliney D, Yang CH, Lee LL. White light-emitting diodes (LEDs) at domestic lighting levels and retinal injury in a rat model. Environ Health Perspect 2014; 122: 269-276.
4. Inoue $\mathrm{Y}$, Iriyama $\mathrm{A}$, Ueno $\mathrm{S}$, et al. Subretinal transplantation ofbone marrow mesenchymal stem cells delays retinal degeneration in the RCS rat model of retinal degeneration. Exp Eye Res 2007; 85:234-241.

5. Minamino $\mathrm{K} 1$, Adachi $\mathrm{Y}$, Yamada $\mathrm{H}$, Higuchi A, Suzuki Y, Iwasaki M, Nakano K, Koike Y, Mukaide H, Kiriyama N, Shigematsu A, Matsumura M, Ikehara S. Long-term survival of bone marrow-derived retinal nerve cells in the retina. Neuroreport 2005; 16 (12):1255-1259.

6. Banin E, Obolensky A, Idelson M, Hemo I, Reinhardtz E, Pikarsky E, Ben-Hur T, Reubinoff B. Retinal incorporation and differentiation of neural precursors derived from human embryonic stem cells. Stem Cells 2006; 24: 246 -257.

7. Schwartz SD, Hubschman JP, Heilwell G, FrancoCardenas V, Pan CK, Ostrick RM, Mickunas E, Gay R, Klimanskaya I, Lanza R. Embryonic stem cell trials for macular degeneration: A preliminary report. Lancet 2012; 379: 713-720.

8. Schwartz SD, Tan G, Hosseini H, Nagiel A. Subretinal transplantation of embryonic stem cell-derived retinal pigment epithelium for the treatment of macular degeneration: An assessment at 4 years. Investig Ophthalmol Vis Sci 2016; 57: ORSFc1-ORSFc9.

9. Seshi B. et al. Multilineage gene expression in human bone marrow stromal cells as evidenced by single- cell microarray analysis. Blood cells, Molecules, and Diseases 2003; 31: 268285-.

10. Velandia SL, Lauro SD, Alonso-Alonso ML, Bartolomé ST, Srivastava GK and Pastor JC, Fernandez-Bueno I. Biocompatibility of intravitreal injection of human mesenchymal stem cells in immunocompetent rabbits. Graefes Arch Clin Exp Ophthalmol 2018; 256:125-134.

11. Wasowicz M, Morice C, Ferrari P, Callebert J, Versaux Botteri C. long term effects of light damage on the retina of albino and pigmented rats. Invest Ophthalmol Vis Sci 2002; 43: 813-820.

12. Castanheira P, Torquetti L, Nehemy MB, Goes AM. Retinal incorporation and differentiation of mesenchymal stem cells intravitreally injected in the injured retina of rats. Arq Bras Oftalmol 2008; 71(5):644-650.

13. Suvarna KS, Layton C, Bancroft JD. Bancroft Bancroft's theory and practice of histological techniques: Expert Consult: Online and print. Churchill Livingstone 2013; 7th ed. Pp. 408 and 418. 
14. Karaoz E, Aksoy A, Ayhan S, Sariboyaci AE, Kaymaz F, Kasap M. Characterization of mesenchymal stem cells from rat bone marrow: ultrastructural properties, differentiation potential and immunophenotypic markers. Histochem Cell Biol 2009; 132(5): 533-546.

15. Yu DY, Cringle SJ. Retinal degeneration and local oxygen metabolism. Exp Eye Res 2005; 80: 745-751.

16. Dong A, Shen J, Krause M, Akiyama H, Hackett $\mathrm{SF}$, Lai $\mathrm{H}$, et al. Superoxide dismutase 1 protects retinal cells from oxidative damage. J Cell Physiol 2006; 208:516-526.

17. Pauley SM. Lighting for the human circadian clock: recent research indicates lighting has become a public health issue. Med Hypotheses 2004; 63: 588-596.

18. Osborne A, Hopes M, Wright $\mathrm{P}$, et al. Human organotypic retinal cultures (HORCs) a chronic experimental model for investigation of retinal ganglion cell degeneration. Exp Eye Res 2016; 143:28-38.

19. Zhang Y, Wang W. Effects of Bone Marrow Mesenchymal Stem Cell Transplantation on LightDamaged Retina. Investigative Ophthalmology and Visual Science 2010; 51(7): 3742- 3748.

20. Strauss $O$. The retinal pigment epithelium in visual function. Physiol Rev 2005; 85: 845-881.

21. Sparrow JR, Hicks D, Hamel CP. The retinal pigment epithelium in health and disease. Curr Mol Med 2010; 10: 802-823.

22. Frank RN, Amin RH, Puklin JE, et al. Antioxidant enzymes in the macular retinal pigment epithelium of eyes with neovascular age-related macular degeneration. American Journal of Ophthalmology 1999; 127 (6): 694-709.

23. Schwartz SD, Regillo CD, Lam BL, Eliott D, Rosenfeld PJ, Gregori NZ, Hubschman JP, Davis JL, Heilwell G, Spirn M, et al. Human embryonic stem cell-derived retinal pigment epithelium in patients with age-related macular degeneration and stargardt's macular dystrophy: Followup of two open-label phase 12/ studies. Lancet 2015; 385: 509-516.

24. Marc RE, Jone BW, Watt CB, Vazquez-Chona F, Vaughan DK, Organisciak DT. Extreme retinal remodeling triggered by light damage: implications for age related macular degeneration. Lancet 2008; 14: 782-805.

25. Ko MK, et al. The role of TLR4 activation in photoreceptor mitochondrial oxidative stress. Invest Ophthalmol Vis Sci 2011; 52: 5824-5835.

26. Kilic U, et al. TLR-4 deficiency protects against focal cerebral ischemia and axotomyinduced neurodegeneration. Neurobiol Dis 2008; 31: 33-40.

27. Yi $\mathrm{H}$, et al. Novel role for the innate immune receptor Toll-like receptor 4 (TLR4) in the regulation of the Wnt signaling pathway and photoreceptor apoptosis. PLoS One. 2012; 7: 36560

28. Chen Q, Long Y, Yuan X, Zou L, Sun J, Chen $\mathrm{S}$, et al. Protective effects of bone marrow stromal cell transplantation in injured rodent brain: synthesis of neurotrophic factors. J Neurosci Res 2005; 80 (5): 611-619.

29. Crigler L, Robey RC, Asawachaicharn A, Gaupp D, Phinney DG. Human mesenchymal stem cell subpopulations express a variety of neuroregulatory molecules and promote neuronal cell survival and neuritogenesis. Exp Neurol 2006; 198 (1): 54-64.

30. Le Blanc K, Ringdén $\mathrm{O}$ et al. Immunobiology of human mesenchymal stem cells and future use in hematopoietic stem cell transplantation. Biol Blood Marrow Transplant 2005; 11(5): 321-334.

31. Otani A, Dorrell MI, Kinder K, Moreno SK, Nusinowitz S, Banin E, Heckenlively J, Friedlander M. Rescue of retinal degeneration by intravitreally injected adult bone marrow-derived lineage-negative hematopoietic stem cells. J Clin Invest 2004; 114: 765-774.

32. Okoye G, Zimmer J, Sung J, et al. Increased expression of brainderived neurotrophic factor preserves retinal function and slows cell death from rhodopsin mutation or oxidative damage. J Neurosci 2003; 23:4164-4172.

33. Hojo M, Abe T, Sugano E, et al. Photoreceptor protection by iris pigment epithelial transplantation transduced with AAV-mediated brain-derived neurotrophic factor gene. Invest Ophthalmol Vis Sci 2004; 45: 3721-3726.

34. Gauthier R, Joly S, Pernet V, et al. Brain-derived neurotrophic factor gene delivery to Muller glia preserves structure and function of light-damaged photoreceptors. Invest Ophthalmol Vis Sci 2005; 46:3383-3392.

35. Kicic A, Shen WY, Wilson AS, Constable IJ, Robertson $\mathrm{T}$, et al. Differentiation of marrow stromal cells into photoreceptors in the rat eye. $\mathrm{J}$ Neurosci 2003; 23: 7742-7749. 
36. Sengupta N, Caballero S, Mames RN, Butler JM, Scott EW, et al. The role of adult bone marrowderived stem cells in choroidal neovascularization. Invest Ophthalmol Vis Sci 2003; 44: 4908-4913.

37. Ritter MR, Banin E, Moreno SK, Aguilar E, Dorrell MI, et al. Myeloid progenitors differentiate into microglia and promote vascular repair in a model of ischemic retinopathy. $\mathrm{J}$ Clin Invest 2006; 116: 3266-3276.

38. Tzameret A, Sher I, Belkin M, Treves AJ, Meir A, Nagler A, Verbin HL, Barshack I, Rosner M, Rotenstreich Y. Transplantation of human bone marrow mesenchymal stem cells as a thin subretinal layer ameliorates retinal degeneration in a rat model of retinal dystrophy. Experimental eye reaserch 2014; 114: 135-144.
39. Ramos JS, Song S, Cardozo F, Hazzi PC, Stedeford TA, Willing T, Freeman TB, Saporta S, Janssen W, Patel N, Cooper DR, Sanberg PR. Adult Bone Marrow Stromal Cells Differentiate into Neural Cells in Vitro. Experimental neurology 2000; 164 (2): 247-256.

40. Colombo E, Farina C. Astrocytes: key regulators of neuroinflammation. Trends Immunol 2016; 37 (9): 608-620.

41. Khakh BS, Sofroniew MV. Diversity of astrocyte functions and phenotypes in neural circuits. Nat Neurosci 2015; 18: 942-952.

42. Chohan A, Singh U, Kumar A, Kaur J. Müller stem cell dependent retinal regeneration. Clinica Chimica Acta 2017; 464: 160-164. 
الملخص العربى

\section{العلاج بالخلايا الجذعية في تلف الشبكية المستحث تجريبياً في الجرذان البيضاء : دراسة هستولوجية}

\section{فيكة حسن كمال الإبيارى ، محمد عبد الرحمن أحمد مكاوى ، عبيز عبد الصمد ، ايمان نجم قسم الهستولوجى ، كلية/لطب ، جامعة عين شمس ، القاهرة ، مصر}

المقدمة : لقد ازداد انحلال الثبكية كسبب شائع للعمى في الوقت الحاضر . يمكن للخلايا الجذعية أن تكون علاجًا واعدًا له.

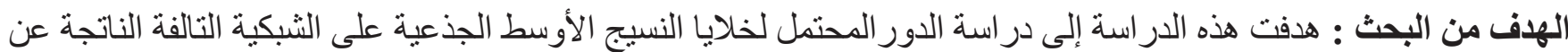

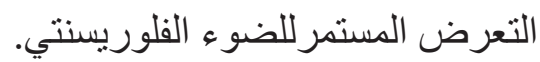
مواد وطرق البحث: تم استخدام 25 جرز ألبينوفى هذه الدراسة. نم استخدام 5 منها تزن 80- 100 جم لتحضيرخلايا النسيج الأوسط الجذعية. واستخدمت العشرين جرزال الأخرى التي تزن 180-200 جم للإجراء التجريبي وتم تقسيمها إلى ثناث

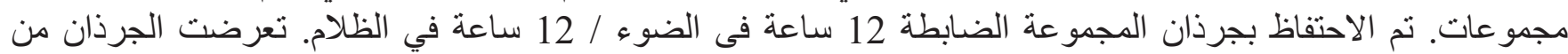

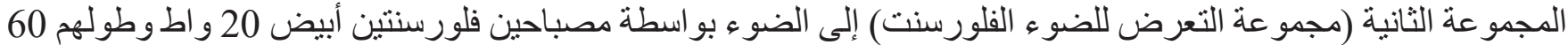

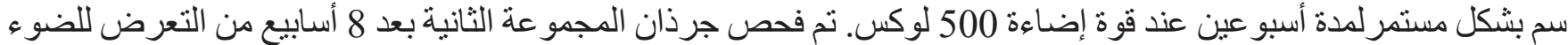

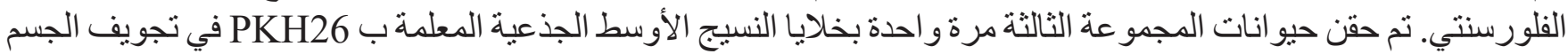

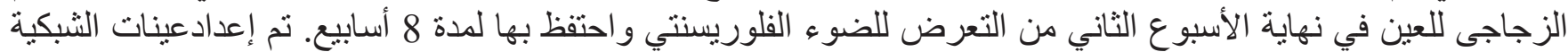
للفحص بالميكروسكوب الضوئي و الإلكتروني. تم إجر اء در اسة مورفومترية و إحصائية.

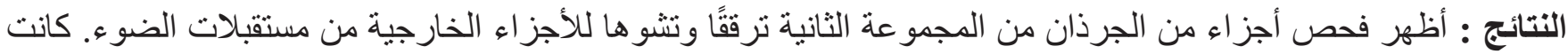

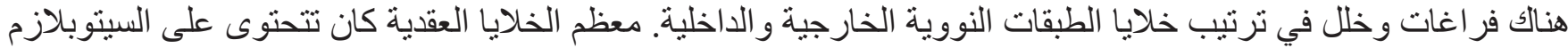

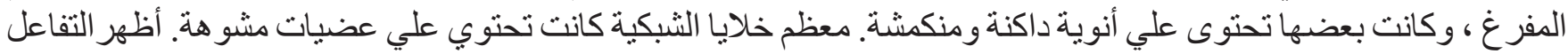

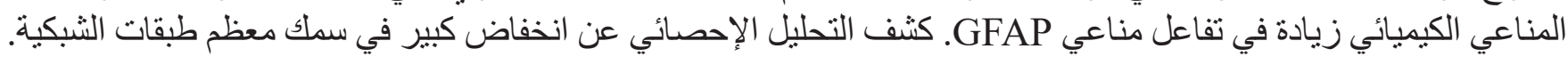
وفي الوقت نفسه، أظهرت شبكية العين بالمجمو عة الثالثة استعادة معظم البنية النسيجية.

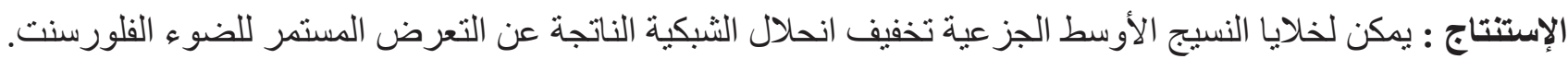

